\title{
Two Classes of Alongside Charge-Transfer Interactions Defined in One [2]Catenane
}

\author{
Sune Nygaard, ${ }^{\dagger, *}$ Stinne W. Hansen, ${ }^{\dagger}$ John C. Huffmann, ${ }^{\star}$ Frank Jensen, ${ }^{\dagger}$ Amar H. Flood ${ }^{\ddagger}{ }^{\ddagger} *$ \\ and Jan O. Jeppesen ${ }^{\dagger}$
}

\section{Supporting Information}

* To whom correspondence may be addressed. E-mail: aflood@indiana.edu

$\dagger$ Department of Physics and Chemistry, University of Southern Denmark, Odense University, Campusvej 55, 5230, Odense M (Denmark)

\$ Department of Chemistry, University of Indiana, Bloomington, 800 E. Kirkwood Ave., Bloomington, IN 47405 (USA) 
CHARACTERIZATION OF THE BISMACROCYCLE 6 BY NMR SPECTROSCOPY---S11

Figure S2 Full ${ }^{1} \mathrm{H}$ NMR spectrum $\left(300 \mathrm{MHz}, \mathrm{CDCl}_{3}\right)$ of the initially isolated bismacrocycle 6 recorded at $298 \mathrm{~K}$

Figure S3 Partial ${ }^{1} \mathrm{H}$ NMR spectrum displaying the aromatic region

$\left(300 \mathrm{MHz}, \mathrm{CDCl}_{3}\right)$ of the initially isolated bismacrocycle 6

recorded at $298 \mathrm{~K}$ $S 13$

Figure S4 Full ${ }^{13} \mathrm{C}$ NMR spectrum $\left(100 \mathrm{MHz}, \mathrm{CDCl}_{3}\right)$ of the PTSA treated bismacrocycle 6 recorded at $298 \mathrm{~K}$ $\mathrm{S} 14$

Table S1 Comparison of ${ }^{13} \mathrm{C}$ NMR spectroscopic dataS16

Figure S5 Full ${ }^{1} \mathrm{H}$ NMR spectrum $\left(300 \mathrm{MHz}, \mathrm{CDCl}_{3}\right)$ of the PTSA treated bismacrocycle 6 at $298 \mathrm{~K}$ S17

Figure S6 Partial ${ }^{1} \mathrm{H}$ NMR spectrum $\left(300 \mathrm{MHz}, \mathrm{CDCl}_{3}\right)$

displaying the aromatic region of the PTSA treated bismacrocycle 6 recorded at $198 \mathrm{~K}$ $\mathrm{S} 18$

CHARACTERIZATION OF 1.4PF 6 BY ${ }^{1} \mathrm{H}$ NMR SPECTROSCOPY $\mathrm{S} 18$

Figure S7 Full ${ }^{1} \mathrm{H}$ NMR spectrum recorded at $298 \mathrm{~K}\left(400 \mathrm{MHz}, \mathrm{CD}_{3} \mathrm{CN}\right)$ of the predominately cis-isomeric [2]catenane $1 \bullet 4 \mathrm{PF}_{6}$ 
Figure S8 Absorption spectra of the TTF unit $\mathbf{5}$ before and after mixing with equimolar amounts of the host $\mathrm{CBPQT}^{4+}$ in $\mathrm{Me}_{2} \mathrm{CO}$ at room temperature

Figure S9 Optimized geometries at the B3LYP//6-31G* level of

(a) the cis-isomer of $\mathbf{1}^{4+}$ and (b) the trans-isomer of $\mathbf{1}^{4+}$ S21

Scheme S1 [2]Pseudorotaxane formation between the model TTF derivative 9 and $\mathrm{CBPQT}^{4+}$ S22

Figure S10 Raman spectroscopic data of $4.5 \mathrm{mM} \mathrm{MeCN}$ solution of (a) the TTF model compound 9, (b) $\mathrm{CBPQT}^{4+}$, and (c) the [2]pseudorotaxane $9 \subset \mathrm{CBPQT}^{4+}$ S23

Table S2 Raman spectroscopic data of $4.5 \mathrm{mM} \mathrm{MeCN}$ solution-

(a) all cis [2]catenane $1^{4+}$, (b) cis/trans [2]catenane $1^{4+}$,

(c) the [2]pseudorotaxane $9 \subset \mathrm{CBPQT}^{4+}$ (d) $\mathrm{CBPQT}^{4+}$, and

(e) the bismacrocycle 6 recorded at $785 \mathrm{~nm}$ laser excitation S24

Figure S11 Raman spectroscopic data of a $110 \mathrm{mM} \mathrm{MeCN}$ solution of the [2]pseudorotaxane $2 \subset \mathrm{CBPQT}^{4+}$ S25 
Figure S12 Non-resonantly enhanced Raman spectra of the solid [2]catenane $\mathbf{1}^{4+}$ recorded at $785 \mathrm{~nm}$ laser excitation-------------------------- S25

Figure S13 Non-resonantly enhanced Raman spectra of solid CBPQT ${ }^{4+}$ recorded at 785 nm laser excitation---- S26

Figure S14 Non-resonantly enhanced Raman spectra of the solid $1: 1$ isomeric mixture of the bismacrocycle 6 recorded at 785 nm laser excitation--

Figure S15 Non-resonantly enhanced Raman spectra of the solid TTF model compound 9 recorded at $785 \mathrm{~nm}$ laser excitation----------------S27

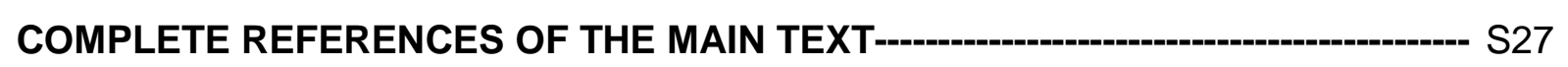




\section{EXPERIMENTAL SECTION}

General. All reactions were carried out under an atmosphere of anhydrous $\mathrm{N}_{2}$ unless otherwise stated. THF was distilled from $\mathrm{Na}$ /benzophenone immediately prior to use. $\mathrm{MeOH}$ was distilled from $\mathrm{Mg}$. DMF, $\mathrm{MeCN}$, and $\mathrm{Me}_{2} \mathrm{CO}$ were allowed to stand over molecular sieves ( $4 \AA$ ) for at least 3 days prior to use. Triethyl phosphite was distilled and stored over molecular sieves ( $4 \AA$ ). All used reagents were standard grade and used as received, except the compounds $\mathbf{2},{ }^{1} \mathbf{5}^{2}$ (Scheme 2), 7•2 $\mathrm{PF}_{6}{ }^{3}$ (Scheme 3), $\mathbf{9}^{4}$ (Scheme $\mathrm{S} 1$ ), and $\mathrm{CBPQT} \cdot 4 \mathrm{PF}_{6}{ }^{3}$ which were all prepared accordingly to literature procedures. Analytical thin layer chromatography (TLC) was performed on Merck DCAlufolien Kiselgel $60 \mathrm{~F}_{254} 0.2 \mathrm{~mm}$ thickness precoated TLC plates, while column chromatography was performed using Merck Kiselgel 60 (0.040-0.063 mm, 230-400 mesh AST0000M). Melting points (mp) were determined on a Büchi apparatus and are uncorrected. ${ }^{1} \mathrm{H}$ NMR spectra were recorded on a Varian Mercury (200 MHz), Varian Gemini (300 MHz), Varian Inova (400 MHz), or Varian Unity (500 MHz) spectrometers at room temperature. Solvent residue was used as internal standard. ${ }^{13} \mathrm{C}$ NMR spectra were recorded on Varian Gemini $(75 \mathrm{MHz})$ or Varian Inova $(100 \mathrm{MHz})$ spectrometers at room temperature. High resolution Fourier Transform matrix-assisted laser-desorption/ionization mass spectrometry (HiResFT-MALDI-MS) was performed on an IonSpec 4.7 tesla Ultima Fourier Transform mass spectrometer, utilizing a 2,5-dihydroxybenzoic acid (DHB) matrix, whereas electrospray ionization (ESI) mass spectra were collected with an IonSpec Ultima 7T FTMS instrument. Cyclic voltammetry (CV) was carried out using MeCN (1.0 $\mathrm{mM})$ as solvent employing $\mathrm{Bu}_{4} \mathrm{NPF}_{6}(0.1 \mathrm{M})$ as the supporting electrolyte, with a scan rate of 200 $\mathrm{mV} \mathrm{s}^{-1}$. Counter and working electrodes were made of platinum while the reference electrode was $\mathrm{Ag} / \mathrm{AgCl}$. Ultraviolet-visible-NIR (UV-vis-NIR) measurements were performed on a Shimadzu UV-1601PC in MeCN at $296 \mathrm{~K}$. Elemental analyses were performed by Atlantic Microlabs, Inc., Atlanta, Georgia. Raman spectra were recorded on a InVia Renishaw Raman Microscope diode 
laser with $785 \mathrm{~nm}$ excitation and Raman shift positions were calibrated to the $520.5 \mathrm{~cm}^{-1}$ band of silicon. Laser powers were adjusted to account for luminescence and photo damage of the NIRabsorbing solid state samples of $\mathbf{1}^{-4} \mathrm{PF}_{6}$ and the acquisition times extended in all cases to ensure a good signal-to-noise. Spectra were baselined where appropriate. Spectra were recorded using a $50 \times$ numerical aperture $(\mathrm{NA})=0.7$ objective lens focused down onto the solid state samples spread out onto a microscope slides. Solution state spectra were recorded using a $50 \times \mathrm{NA}=0.7$ long working distance objective lens to focus into the $4.5 \mathrm{mM} \mathrm{MeCN}$ solution inside a stoppered $1 \mathrm{~mm}$ quartz cuvette. Short acquisition time spectra were recorded before and after long acquisitions to ensure no damage to the samples. The solution samples of $\mathbf{9} \subset \mathbf{C B P Q T}^{4+}$ was achieved by mixing together equimolar $(4.5 \mathrm{mM})$ solutions of the TTF derivative 9 and $\mathbf{C B P Q T}^{4+}$ and allowing the solution to equilibrate towards the formation of the [2]pseudorotaxane $\mathbf{9} \subset \mathbf{C B P Q T} \mathbf{T}^{4+}$ as confirmed by UV-vis-NIR absorption spectroscopy. The solution samples of $2 \subset \mathbf{C B P Q T}^{4+}$ was achieved by mixing together equimolar $(110 \mathrm{mM})$ solutions of the TTF derivative $\mathbf{2}$ and $\mathbf{C B P Q T}^{4+}$ and allowing the solution to equilibrate towards the formation of the [2]pseudorotaxane $\mathbf{2 \subset C B P Q T} \mathbf{C}^{4+}$ as confirmed by UV-vis-NIR absorption spectroscopy.

\section{Methanesulfonic acid 2-\{2-[2-(4-\{2-[2-(2-methanesulfonyloxy-ethoxy)-ethoxy]-ethoxy\}-} phenoxy)-ethoxy]-ethoxy -ethyl ester (3). To a solution of compound 2 (570 $\mathrm{mg}, 1.50 \mathrm{mmol}$ ) and $\mathrm{Et}_{3} \mathrm{~N}(1.5 \mathrm{~g}, 15 \mathrm{mmol})$ in $\mathrm{CH}_{2} \mathrm{Cl}_{2}(50 \mathrm{~mL}) \mathrm{MsCl}(516 \mathrm{mg}, 4.5 \mathrm{mmol})$ was added dropwise over $10 \mathrm{~min}$. The clear slightly yellow solution was then stirred for $1 \mathrm{~h}$ at room temperature, whereafter the reaction was terminated by the addition of $\mathrm{H}_{2} \mathrm{O}(100 \mathrm{~mL})$. The organic phase was separated and subsequently washed with $\mathrm{H}_{2} \mathrm{O}(2 \times 100 \mathrm{~mL})$ and dried $\left(\mathrm{MgSO}_{4}\right)$ Removal of the solvent in vacuo gave the crude product 3 as a yellow oil. Column chromatography $\left(\mathrm{SiO}_{2}, \mathrm{CH}_{2} \mathrm{Cl}_{2}: \mathrm{MeOH}\right.$ v/v 9:1) afforded the pure product 3 as a white solid (810 mg, quantitatively): mp $90-92{ }^{\circ} \mathrm{C}$; ${ }^{1} \mathrm{H}$ NMR 
$\left(\mathrm{CDCl}_{3}, 300 \mathrm{MHz}\right) \delta 3.05(\mathrm{~s}, 6 \mathrm{H}), 3.70-3.84(\mathrm{~m}, 16 \mathrm{H}), 4.05-4.07(\mathrm{~m}, 4 \mathrm{H}), 4.36-4.39(\mathrm{~m}, 4 \mathrm{H}) 6.83$

$(\mathrm{s}, 4 \mathrm{H}) ;{ }^{13} \mathrm{C} \mathrm{NMR}\left(\mathrm{CDCl}_{3}, 75 \mathrm{MHz}\right) \delta 37.7,68.0,69.0,69.3,69.9,70.65,70.71,115.5,153.1$;

$\operatorname{MS}(E S I) m / z 553\left([\mathrm{M}+\mathrm{Na}]^{+}, 100\right), 530\left(\mathrm{M}^{+}, 2\right)$; MS (HiResESI) calcd for $\mathrm{C}_{20} \mathrm{H}_{34} \mathrm{O}_{12} \mathrm{~S}_{2}$ 553.1384;

found 553.1397. Anal. Calcd. for $\mathrm{C}_{20} \mathrm{H}_{34} \mathrm{O}_{12} \mathrm{~S}_{2} \bullet 0.5 \mathrm{H}_{2} \mathrm{O}$ : C, 44.52; H, 6.54; S, 11.88. Found: C, 44.18; H, 6.30; S, 11.88 .

1,4-Bis-\{2-[2-(2-iodoethoxy)-ethoxy]-ethoxy\}-benzene (4). Compound 3 (810 mg, $1.52 \mathrm{mmol})$ and $\mathrm{NaI}(2.2 \mathrm{~g}, 15 \mathrm{mmol})$ was dissolved in anhydrous $\mathrm{Me}_{2} \mathrm{CO}(50 \mathrm{~mL})$. The initial colorless solution was stirred at reflux for $20 \mathrm{~h}$, during which time the solution turns yellow and unclear. The reaction mixture was cooled to room temperature, where after the solvent was removed in vacuo. The resulting yellow oil was redissolved in $\mathrm{CH}_{2} \mathrm{Cl}_{2}(150 \mathrm{~mL})$ and washed with a $10 \% \mathrm{v} / \mathrm{v}$ aqueous solution of $\mathrm{Na}_{2} \mathrm{~S}_{2} \mathrm{O}_{3}(2 \times 100 \mathrm{~mL}), \mathrm{H}_{2} \mathrm{O}(100 \mathrm{~mL})$, and dried $\left(\mathrm{MgSO}_{4}\right)$. Removal of the solvent gave a slightly yellow oil, which was purified by column chromatography $\left(\mathrm{SiO}_{2}, \mathrm{CH}_{2} \mathrm{Cl}_{2}: \mathrm{MeOH}\right.$ v/v 92:8) providng the product 4 as a clear, slightly yellow oil $(0.77 \mathrm{~g}, 86 \%) ;{ }^{1} \mathrm{H} \mathrm{NMR}\left(\mathrm{CDCl}_{3}, 300\right.$ MHz) $\delta 3.26(\mathrm{~d}, J=6.9 \mathrm{~Hz}, 4 \mathrm{H}), 3.68-3.86(\mathrm{~m}, 16 \mathrm{H}), 4.06-4.08(\mathrm{~m}, 4 \mathrm{H}), 6.84(\mathrm{~s}, 4 \mathrm{H}) ;{ }^{13} \mathrm{C} \mathrm{NMR}$ $\left(\mathrm{CDCl}_{3}, 75 \mathrm{MHz}\right) \delta 2.9,68.1,70.0,70.3,70.8,72.0,115.6,153.1 ; \mathrm{MS}(\mathrm{ESI}) \mathrm{m} / z 617\left(\left[\mathrm{M}^{+}+\mathrm{Na}\right]\right.$ 100); MS(HiResESI) calcd for $\mathrm{C}_{18} \mathrm{H}_{28} \mathrm{I}_{2} \mathrm{O}_{6} \mathrm{Na}$ 616.9826; found 616.9840. Anal. Calcd. for $\mathrm{C}_{18} \mathrm{H}_{28} \mathrm{I}_{2} \mathrm{O}_{6}: \mathrm{C}, 36.38 ; \mathrm{H}, 4$.75. Found: $\mathrm{C}, 36.68 ; \mathrm{H}, 4.82$.

Bismacrocycle 6 (1:1 cis/trans). Compound 5 (cis/trans) (660 mg, $1.14 \mathrm{mmol}$ ) was dissolved in anhydrous DMF (40 mL) and degassed thoroughly with argon. $\mathrm{CsOH} \bullet \mathrm{H}_{2} \mathrm{O}(392 \mathrm{mg}, 2.33 \mathrm{mmol})$ dissolved in anhydrous $\mathrm{MeOH}(2 \mathrm{~mL})$ was added dropwise over $30 \mathrm{~min}$ to the yellow solution of $\mathbf{5}$, which resulted in a color change from orange to blackish-orange when stirred for $1 \mathrm{~h}$. Subsequently, this solution and a solution of $4(750 \mathrm{mg}, 1.26 \mathrm{mmol})$ in anhydrous DMF (42 mL) were added simultaneously during $10 \mathrm{~h}$ to DMF $(80 \mathrm{~mL})$ by employing a perfusor pump. After addition was completed, stirring was continued for additional $10 \mathrm{~h}$. The reaction mixture was then concentrated 
in vacuo and redissolved in $\mathrm{CH}_{2} \mathrm{Cl}_{2}(100 \mathrm{~mL})$, washed with $\mathrm{H}_{2} \mathrm{O}(150 \mathrm{~mL})$, and dried $\left(\mathrm{MgSO}_{4}\right.$.). Removal of the solvent yielded a orange oil, from which $\mathbf{6}$ was isolated as a 1:1 mixture of the cisand the trans-isomer by column chromatography $\left(\mathrm{SiO}_{2}, \mathrm{CH}_{2} \mathrm{Cl}_{2}:\right.$ EtOAc v/v 9:1) as an yellow oil contaminated with a small amount of the starting material $4(750 \mathrm{mg}, 82 \%) ;{ }^{1} \mathrm{H} \mathrm{NMR}\left(\mathrm{CDCl}_{3}\right.$, $300 \mathrm{MHz}) \delta$ 0.91-0.96 (m, 2H), 1.33-1.39 (m, 10H), 1.61-1.69 (m, 4H), 2.75-2.80 (m, 2H), 2.96-3.10 (m, 6H), 3.62-3.84 (m, 16H), 4.09-4.14 (m, 4H), $6.82(\mathrm{~s}, 2 \mathrm{H}), 6.89(2 \mathrm{H}) .{ }^{1} \mathrm{H}$ NMR $\left(\mathrm{CD}_{3} \mathrm{CN}, 200 \mathrm{MHz}\right) \delta 0.88-0.93(\mathrm{~m}, 2 \mathrm{H}), 1.31-1.38(\mathrm{~m}, 10 \mathrm{H}), 1.58-1.66(\mathrm{~m}, 4 \mathrm{H}), 2.78-2.85(\mathrm{~m}$ 2H), 2.92-3.05 (m, 6H), 3.58-3.75 (m, 16H), 4.02-4.07 (m, 4H), $6.81(\mathrm{~s}, 2 \mathrm{H}), 6.87(\mathrm{~s}, 2 \mathrm{H})$; ${ }^{13} \mathrm{C} \mathrm{NMR}\left(\mathrm{CDCl}_{3}, 100 \mathrm{MHz}\right) \delta 26.6,27.6,27.7,28.3,28.6,30.5,30.8,31.0,35.2,35.6,35.6,35.9$, $68.3,68.5,69.8,69.9,70.1,70.4,70.6,70.6,71.0,71.1,112.2,113.8,115.6,116.0,125.3,128.1$, 129.0, 129.9, 153.1, 153.1; MS(MALDI) $m / z 831\left(\left[\mathrm{M}^{+}+\mathrm{Na}\right], 10\right), 809\left(\mathrm{M}^{+}, 100\right), 772(60), 617$ (100); MS(HiResESI) calcd for $\mathrm{C}_{34} \mathrm{H}_{48} \mathrm{O}_{6} \mathrm{~S}_{8} \mathrm{Na}$ 831.1109; found 831.1110. Anal. Calcd. for $\mathrm{C}_{34} \mathrm{H}_{48} \mathrm{O}_{6} \mathrm{~S}_{8}: \mathrm{C}, 50.46 ; \mathrm{H}, 5.98$. Found: $\mathrm{C}, 50.11 ; \mathrm{H}, 6.07$.

Bismacrocycle 6 (9:1 cis/trans). The bismacrocycle 6 (145 $\mathrm{mg}, 0.18 \mathrm{mmol})$ was dissolved in anhydrous $\mathrm{Me}_{2} \mathrm{CO}$ and a catalytic amount of PTSA was added in one portion. The yellow solution was stirred at room temperature for $24 \mathrm{~h}$ before the solvent was removed in vacuo. The resulting yellow solid was redissolved in $\mathrm{CH}_{2} \mathrm{Cl}_{2}(30 \mathrm{~mL})$ and washed with a saturated aqueous solution of $\mathrm{NaHCO}_{3}(25 \mathrm{~mL}), \mathrm{H}_{2} \mathrm{O}(2 \times 250 \mathrm{~mL})$, and dried $\left(\mathrm{MgSO}_{4}\right)$. The solvent was then removed in vacuo yielding predominately (9:1) the cis-bismacrocyclic compound 6 as a yellow oil (140 mg, 97\%); ${ }^{1} \mathrm{H}$ NMR $\left(\mathrm{CDCl}_{3}, 300 \mathrm{MHz}\right) \delta 0.91-0.96(\mathrm{~m}, 2 \mathrm{H}), 1.33-1.39(\mathrm{~m}, 10 \mathrm{H}), 1.61-1.69(\mathrm{~m}, 4 \mathrm{H})$, 2.75-2.80 (m, 2H), $2.96(\mathrm{t}, J=6.8 \mathrm{~Hz}, 6 \mathrm{H}), 3.62-3.84(\mathrm{~m}, 16 \mathrm{H}), 4.09-4.14(\mathrm{~m}, 4 \mathrm{H}), 6.81(\mathrm{~s}, 0.4 \mathrm{H})$, 6.87 (s, 3.6H). ${ }^{1} \mathrm{H}$ NMR $\left(\mathrm{CD}_{3} \mathrm{CN}, 200 \mathrm{MHz}\right) \delta$ 0.88-0.93 (m, 2H), 1.31-1.38 (m, 10H), 1.58-1.66 (m, 4H), 2.78-2.85 (m, 2H), 2.92-3.05 (m, 6H), 3.58-3.75 (m, 16H), 4.02-4.07 (m, 4H), 6.81 (s, 
$0.4 \mathrm{H}), 6.87(\mathrm{~s}, 3.6 \mathrm{H}) ;{ }^{13} \mathrm{C} \mathrm{NMR}\left(\mathrm{CDCl}_{3}, 100 \mathrm{MHz}\right)^{5} \delta 27.6,27.7,28.3,30.5,35.6,35.9,68.5,69.9$, 70.1, 70.6, 71.0, 112.2, 116.0, 125.3, 129.9, 153.1.

Catenane 1•4PF - Method A. The 1:1 cis- and trans-isomeric mixture of the bismacrocycle 6 (180 mg, $0.22 \mathrm{mmol}), \mathbf{7} \cdot 2 \mathrm{PF}_{6}(530 \mathrm{mg}, 0.75 \mathrm{mmol})$, and 8 (200 mg, $\left.0.75 \mathrm{mmol}\right)$ were dissolved in anhydrous DMF (12 mL). The yellow reaction mixture was subjected to $10 \mathrm{kBar}$ at room temperature for $3 \mathrm{~d}$. The intense green solution was directly subjected to column chromatography $\left(\mathrm{SiO}_{2}\right)$. Unreacted macrocycle 6 was eluted with $\mathrm{Me}_{2} \mathrm{CO}$, whereupon the eluent was changed to $\mathrm{Me}_{2} \mathrm{CO} / \mathrm{NH}_{4} \mathrm{PF}_{6}\left(1.0 \mathrm{~g} \mathrm{NH}_{4} \mathrm{PF}_{6}\right.$ per $\left.100 \mathrm{~mL} \mathrm{Me}_{2} \mathrm{CO}\right)$ and the green band was collected. Most of the solvent was removed in vacuo followed by addition of $\mathrm{H}_{2} \mathrm{O}(25 \mathrm{~mL})$. The resulting green precipitate was collected by filtration yielding the desired [2]catenane $1 \bullet 4 \mathrm{PF}_{6}$ as a green solid consisting of a mixture (67:33) of the cis- and the trans-isomer $(50 \mathrm{mg}, 9 \%): \mathrm{mp}>250{ }^{\circ} \mathrm{C}:{ }^{1} \mathrm{H} \mathrm{NMR}\left(\mathrm{CD}_{3} \mathrm{CN}\right.$, $500 \mathrm{MHz}, 298 \mathrm{~K}) \delta 1.21-1.33(\mathrm{~m}, 12 \mathrm{H}), 1.46-1.61(\mathrm{~m}, 4 \mathrm{H}), 2.71-2.96(\mathrm{~m}, 8 \mathrm{H}), 3.57(\mathrm{~s}, 4 \mathrm{H})$ 3.55-4.03 (m, 20), $5.71(\mathrm{bs}, 8 \mathrm{H}), 7.77(\mathrm{~s}, 2.6 \mathrm{H}), 7.79(\mathrm{~s}, 5.4 \mathrm{H}), 7.87(\mathrm{~d}, J=6.8 \mathrm{~Hz}, 8 \mathrm{H}), 8.96(\mathrm{~d}$, $J=6.8 \mathrm{~Hz}, 8 \mathrm{H}) ; \mathrm{MS}(\mathrm{ESI}) \mathrm{m} / z 808\left([\text { dumbbell }]^{+}, 40\right), 809\left(\left[\mathrm{M}-2 \mathrm{PF}_{6}\right]^{2+}, 100\right)$. Anal. Calcd. for $\mathrm{C}_{70} \mathrm{H}_{80} \mathrm{~F}_{4} \mathrm{~N}_{4} \mathrm{O}_{6} \mathrm{P}_{4} \mathrm{~S}_{8}: \mathrm{C}, 44.02 ; \mathrm{H}, 4.22 ; \mathrm{N}, 2.93 ; \mathrm{S}, 13.43$. Found: C, 43.91; H, 4.43; N, 2.96; S, 13.59 .

Catenane 1•4PF $\mathbf{6}-$ Method B. The PTSA treated bismacrocycle $6(140 \mathrm{mg}, 0.18 \mathrm{mmol}), \mathbf{7} \bullet 2 \mathrm{PF}_{6}$ (380 mg, $0.53 \mathrm{mmol})$, and 8 (140 $\mathrm{mg}, 0.53 \mathrm{mmol})$ were dissolved in anhydrous DMF $(8 \mathrm{~mL})$. The yellow reaction mixture was subjected to $10 \mathrm{kBar}$ at room temperature for 3 days. The intense green solution was directly subjected to column chromatography $\left(\mathrm{SiO}_{2}\right)$. Unreacted macrocycle 6 was eluted with $\mathrm{Me}_{2} \mathrm{CO}$, whereupon the eluent was changed to $\mathrm{Me}_{2} \mathrm{CO} / \mathrm{NH}_{4} \mathrm{PF}_{6}\left(1.0 \mathrm{~g} \mathrm{NH}_{4} \mathrm{PF}_{6}\right.$ per $100 \mathrm{~mL} \mathrm{Me} 2 \mathrm{CO}$ ) and the green band was collected. Most of the solvent was removed in vacuo followed by addition of $\mathrm{H}_{2} \mathrm{O}(25 \mathrm{~mL})$. The resulting green precipitate was collected by filtration yielding the desired [2] catenane $1 \bullet 4 \mathrm{PF}_{6}$ as a green solid consisting mainly (99:5) of the cis-isomer 
(54 mg, 16\%): $\mathrm{mp}>250{ }^{\circ} \mathrm{C} ;{ }^{1} \mathrm{H}$ NMR $\left(\mathrm{CD}_{3} \mathrm{CN}, 400 \mathrm{MHz}, 298 \mathrm{~K}\right) \delta 1.30-1.34(\mathrm{~m}, 12 \mathrm{H}), 1.49-1.55$

(m, 4H), 2.73-2.86 (m, 8H), $3.57(\mathrm{~s}, 4 \mathrm{H}), 3.68-3.96(\mathrm{~m}, 20 \mathrm{H}), 5.71(\mathrm{bs}, 8 \mathrm{H}), 7.80(\mathrm{~s}, 8 \mathrm{H}), 7.87(\mathrm{~d}$ $J=6.6 \mathrm{~Hz}, 8 \mathrm{H}), 8.96(\mathrm{~d}, J=6.6 \mathrm{~Hz}, 8 \mathrm{H}) ; \mathrm{MS}(\mathrm{ESI}) \mathrm{m} / \mathrm{z} 808\left([\text { dumbbell }]^{+}, 40\right), 809\left(\left[\mathrm{M}-2 \mathrm{PF}_{6}\right]^{2+}\right.$, $100)$.

Crystal structure analysis: Slow diffusion of $i \mathrm{PrOH}$ into a $\mathrm{CD}_{3} \mathrm{CN}$ solution of the [2]catenane $1 \bullet 4 \mathrm{PF}_{6}$, obtained from the clipping reaction of the (9:1) cis-isomeric bismacrocycle 6 gave orange needle-like crystals suitable for X-ray diffraction analysisThe sample consisted of very thin plates growing in clumps in the crystallization media. Crystals were pipetted into octanol to prevent loss of solvent. A typical yellow plate of approximate dimensions $0.30 \times 0.12 \times 0.03 \mathrm{~mm}$ was transferred onto the tip of a $0.02 \mathrm{~mm}$ diameter glass fiber which was subsequently mounted on a SMART6000 (Bruker) and cooled to 133(2) K. A preliminary set of cell constants was calculated from reflections obtained from three nearly orthogonal sets of 20 frames. The data collection was carried out using graphite monochromated Mo K $\alpha$ radiation with a frame time of 60 seconds and a detector distance of $5.0 \mathrm{~cm}$. A randomly oriented region of a sphere in reciprocal space was surveyed. Four sections of 606 frames were collected with $0.30^{\circ}$ steps in $\omega$ at different $\phi$ settings with the detector set at $-43^{\circ}$ in $2 \theta$. Final cell constants were calculated from the xyz centroids of 1766 strong reflections from the actual data collection after integration (SAINT). Intensity statistics and systematic absences suggested the centrosymmetric triclinic space group P-1 and subsequent solution and refinement confirmed this choice. The structure was solved using SHELXS-97 and refined with SHELXL-97. A direct-methods solution was calculated which provided most nonhydrogen atoms from the E-map. Full-matrix least squares / difference Fourier cycles were performed which located the remaining non-hydrogen atoms. In addition to the cation four $\mathrm{PF}_{6}^{-}$ anions and seven $\mathrm{CD}_{3} \mathrm{CN}$ solvent molecules were located. There is disorder in one of the $\mathrm{CD}_{3} \mathrm{CN}$ 
solvent molecules and one anion. The $-\left(\mathrm{CH}_{2}\right)_{10}-$ chain exhibits significant vibrational flexibility, but no discrete disorder was observed. Some restraints were applied to smooth convergence. All non-hydrogen atoms with the exception of several of the disordered atoms in the solvent and anion were refined with anisotropic displacement parameters. Where possible, hydrogen atoms were located in subsequent Fourier maps and included as isotropic contributors in the final cycles of refinement. All remaining hydrogen atoms were placed in ideal positions and refined as riding atoms with relative isotropic displacement parameters. The thermal ellipsoid drawing $(50 \%)$ of the [2] catenane $1 \bullet 4 \mathrm{PF}_{6}$ is shown in Figure $\mathrm{S} 1$.

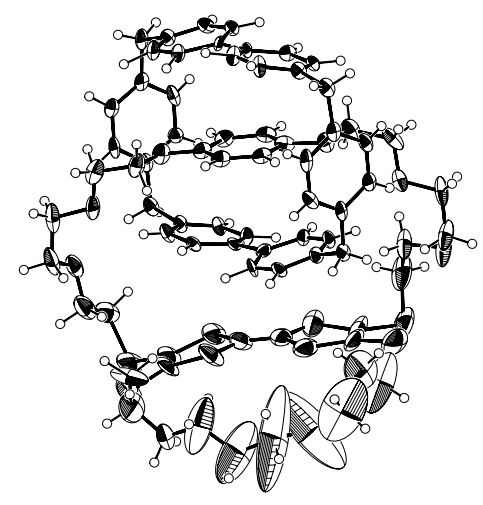

Figure S1. The thermal ellipsoids $(50 \%)$ drawing of the [2]catenane $1 \bullet 4 \mathrm{PF}_{6}$.

\section{CHARACTERIZATION OF THE BISMACROCYCLE 6 BY NMR SPECTROSCOPY}

The bismacrocyclic compound $\mathbf{6}$ isolated from the reaction between the bulky TTF containing macrocycle 5 and the HQ containing thread $\mathbf{4}$ was analyzed by ${ }^{1} \mathrm{H}$ NMR spectroscopy in various solvents. The data recorded in $\mathrm{CDCl}_{3}$ is shown in Figure $\mathrm{S} 2$. 


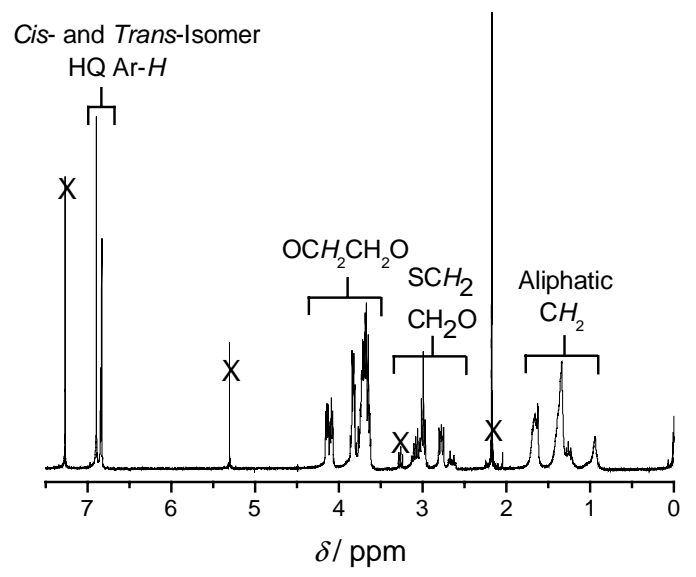

Figure S2. Full ${ }^{1} \mathrm{H}$ NMR spectrum $\left(300 \mathrm{MHz}, \mathrm{CDCl}_{3}\right)$ of the cis/trans isomeric mixture $(\sim 1: 1)$ of the bismacrocycle 6 recorded at $298 \mathrm{~K}$.

The bismacrocycle 6 was found to consist as an approximate 1:1 mixture of the cis-and the transisomers immediately after dissolution in both $\mathrm{CDCl}_{3}$ and $\mathrm{CD}_{3} \mathrm{CN}$ as evaluated by the relative intensities of the HQ Ar- $H$ signals originating (Figure 2 and Figure S2) from the cis- and the transisomers, respectively. It is also evident from the ${ }^{1} \mathrm{H}$ NMR (Figure S3 marked by an asterisk *) and ${ }^{13} \mathrm{C}$ NMR spectroscopic data (Figure S4 marked by an asterisk *) that the isolated bismacrocycle 6 is contaminated with a small amount of the starting diiodide 4 . However, further attempts to remove the impurity by means of column chromatography and preparative thin layer chromatography proved unsuccessful. It was therefore decided to proceed with the high-pressure clipping reaction as the impurity of the diiodide compound $\mathbf{4}$ was not expected to affect the outcome of the subsequent clipping reaction and easily could be removed during purification of the [2]catenane $1 \bullet 4 \mathrm{PF}_{6}$. 


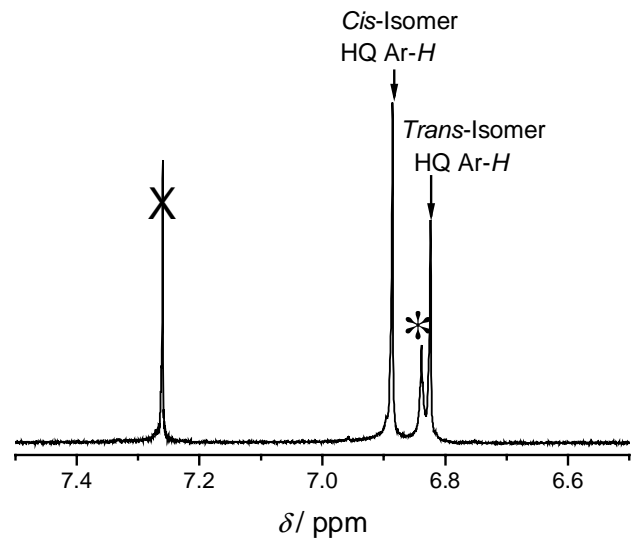

Figure S3. Partial ${ }^{1} \mathrm{H}$ NMR spectrum displaying the aromatic region $\left(300 \mathrm{MHz}, \mathrm{CDCl}_{3}\right)$ of the initially isolated bismacrocycle 6 recorded at $298 \mathrm{~K}$. The peak marked by an asterisk (*) arises from the contamination of the bismacrocycle 6 with the starting diiodide 4.

It was observed that adding acid to the bismacrocycle 6, either by dissolving it in and storing it for hours in slightly acidic $\mathrm{CDCl}_{3}$ or by adding PTSA, changed the isomeric ratio from approximately 1:1 to approximately 9:1 in favor of the cis-isomer, as evaluated by comparing the relative intensities of the HQ Ar- $H$ signals. The assignment of the major isomer to the $c i s$-system was made possible by using the ${ }^{13} \mathrm{C}$ NMR spectroscopic data previously ${ }^{2}$ reported for the purified cis- and trans-isomers of the bulky TTF containing macrocycle 5. A comparison of the key areas of the ${ }^{13} \mathrm{C}$ NMR spectra of the known cis-macrocycle 5 and the bismacrocycle $\mathbf{6}$ (Figure S4) obtained after treatment with PTSA reveals that the major isomer of $\mathbf{6}$ is the cis-compound. 


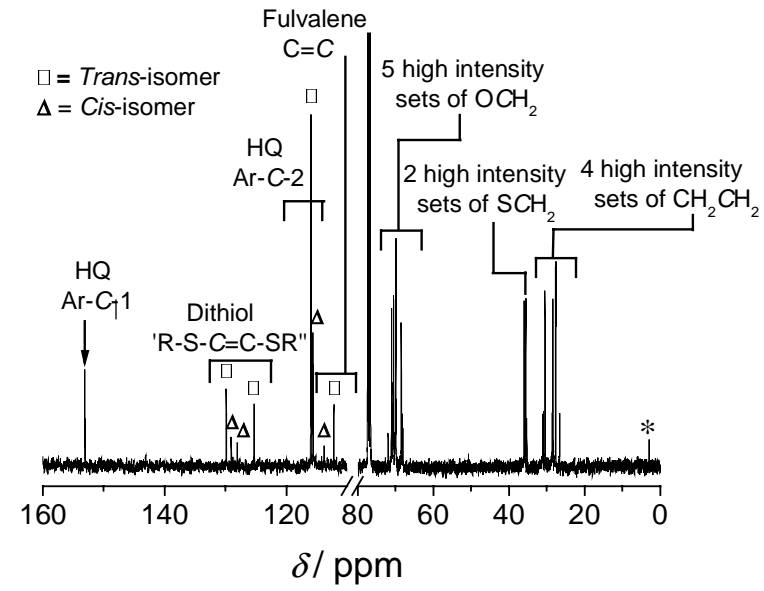

Figure S4. Full ${ }^{13} \mathrm{C}$ NMR spectrum $\left(100 \mathrm{MHz}, \mathrm{CDCl}_{3}\right)$ of the PTSA treated bismacrocycle 6 recorded at $298 \mathrm{~K}$. The peak marked by an asterisk $(*)$ arises from the contamination of the bismacrocycle 6 with the starting material 4 .

Table 1 provides an overview on how the assignment of the signals associated with the bismacrocycle 6 was established. The ${ }^{13} \mathrm{C}$ NMR spectrum of the bismacrocycle 6 after treatment with PTSA was compared with the ${ }^{13} \mathrm{C}$ NMR spectra of the cis- and the trans-isomers of $\mathbf{5}$, respectively. This analysis revealed that most of the signals present with high intensity in the ${ }^{13} \mathrm{C}$ NMR spectrum of the bismacrocycle 6 correlates well with similar signals observed in the ${ }^{13} \mathrm{C}$ NMR spectrum of the cis-macrocycle 5. The low intensity peaks observed in the ${ }^{13} \mathrm{C}$ NMR spectrum of the bismacrocycle 6 on the other hand correlates well with similar signals observed in the ${ }^{13} \mathrm{C}$ NMR spectrum of the trans-macrocycle 5. There is a fault free correlation between the relative positions of all the signals from the aliphatic $\mathrm{CH}_{2}$ chain $(\delta=25-40 \mathrm{ppm})$ and between the fulvalene $\mathrm{C}=\mathbf{C}$ signals $(\delta=112-114 \mathrm{ppm})$. The correlation between the signals in the ${ }^{13} \mathrm{C}$ NMR spectra of the cis-isomer of $\mathbf{5}$ and the major peaks in the PTSA treated bismacrocycle $\mathbf{6}$ does not fit for the dithiole (R'S-C=C-SR) part of the spectra $(\delta=125-130 \mathrm{ppm})$. However, this is not surprising as these are the signals expected to be most significantly influenced by the change in environment when going from the doubly cyanoethylthio substituted macrocycle $\mathbf{5}$ to the 
bismacrocycle 6, on account of the very different electronic properties of the groups attached to the sulphur atom when going from compound 5 to 6 . All signals in the bismacrocycle $\mathbf{6}$ that corresponds to the introduction of the HQ unit, i.e. signals arising from the aromatic HQ unit and the $\mathrm{CH}_{2}$ signals from the glycol-chains, are omitted in the analysis for obvious reasons. 
Table S1. Comparison of ${ }^{13} \mathrm{C}$ NMR data between the cis-and the trans-isomers of the macrocyclic compound 5 and the PTSA treated bismacrocycle $\mathbf{6}$.

\begin{tabular}{|c|c|c|}
\hline $\begin{array}{l}\text { Compound } 5 \\
\text { Trans }\end{array}$ & PTSA treated bismacrocycle 6 & $\begin{array}{l}\text { Compound } 5 \\
\text { Cis }\end{array}$ \\
\hline $18.8^{a}\left(\mathrm{CH}_{2} \mathrm{CN}\right)$ & & $18.7^{a}\left(\mathrm{CH}_{2} \mathrm{CN}\right)$ \\
\hline \multirow[t]{4}{*}{$26.8 \rightarrow$} & 26.6 (Minor peak) & \\
\hline & 27.6 & $\leftarrow 27.5$ \\
\hline & 27.7 & $\leftarrow 27.6$ \\
\hline & 28.3 & $\leftarrow 28.2$ \\
\hline \multirow[t]{2}{*}{$28.8 \rightarrow$} & 28.6 (Minor peak) & \\
\hline & 30.5 & $\leftarrow \mathbf{3 0 . 6}$ \\
\hline $30.7 \rightarrow$ & 30.8 (Minor peak) & \\
\hline $31.2^{a}\left(\mathrm{SCH}_{2} \mathrm{CH}_{2}\right)$ & & $31.3^{a}\left(\mathrm{SCH}_{2} \mathrm{CH}_{2}\right)$ \\
\hline \multirow[t]{2}{*}{$31.6 \rightarrow$} & $\begin{array}{l}\text { 31.0 (Minor peak) } \\
35.2^{b}\end{array}$ & \\
\hline & 35.6 & $\leftarrow 35.7$ \\
\hline \multirow[t]{2}{*}{$35.7 \rightarrow$} & $\begin{array}{l}\text { 35.6 (Minor peak) } \\
35.9^{b} \\
68.3^{b} \\
68.5^{b} \\
69.8^{b} \\
69.9^{b} \\
70.1^{b} \\
70.4^{b} \\
70.6^{b} \\
70.6^{b} \\
71.0^{b} \\
71.1^{b}\end{array}$ & \\
\hline & 112.2 & $\leftarrow 112.5$ \\
\hline $114.5 \rightarrow$ & 113.8 (Minor peak) & \\
\hline \multirow[t]{2}{*}{$117.3^{a}\left(\mathrm{CH}_{2} \mathrm{CN}\right)$} & $\begin{array}{l}115.6^{b} \\
116.0^{b}\end{array}$ & $117.6^{a}\left(\mathrm{CH}_{2} \mathrm{CN}\right)$ \\
\hline & 125.3 & $\leftarrow 120.9$ \\
\hline $125.1 \rightarrow$ & 128.1 (Minor peak) & \\
\hline \multirow{3}{*}{$132.4 \rightarrow$} & 129.0 (Minor peak) & \\
\hline & 129.9 & $\leftarrow 134.4$ \\
\hline & $\begin{array}{l}153.1^{b} \\
153.1^{b}\end{array}$ & \\
\hline
\end{tabular}

${ }^{a}$ Signals arising from the cyanoethylthio $\left(\mathrm{SCH}_{2} \mathrm{CH}_{2} \mathrm{CN}\right)$ has been discounted in the assignment.

${ }^{b}$ New signal arising from the introduction of the HQ containing part of the bismacrocycle. 
It is not possible to determine whether it is the cis- or the trans-isomer that has been isolated before or after treatment with PTSA from the ${ }^{1} \mathrm{H}$ NMR spectrum alone. Nevertheless, a marked simplification was observed of the ${ }^{1} \mathrm{H}$ NMR spectrum of the bismacrocycle 6 before (Figure S2) and after (Figure S5) treatment with PTSA.

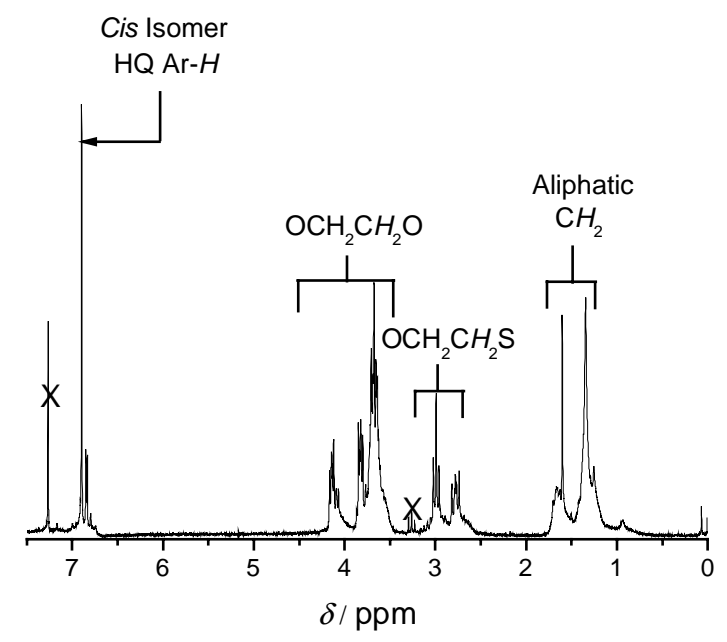

Figure S5. Full ${ }^{1} \mathrm{H}$ NMR spectrum $\left(300 \mathrm{MHz}, \mathrm{CDCl}_{3}\right)$ of the PTSA treated bismacrocycle 6 recorded at $298 \mathrm{~K}$.

The isomeric distribution has changed to approximately 9:1 in favor of the cis-isomer. The evaluation of the relative intensities was carried out by the integration (Figure S6) of the two signals associated with the resonances of the HQ Ar- $H$ protons. 


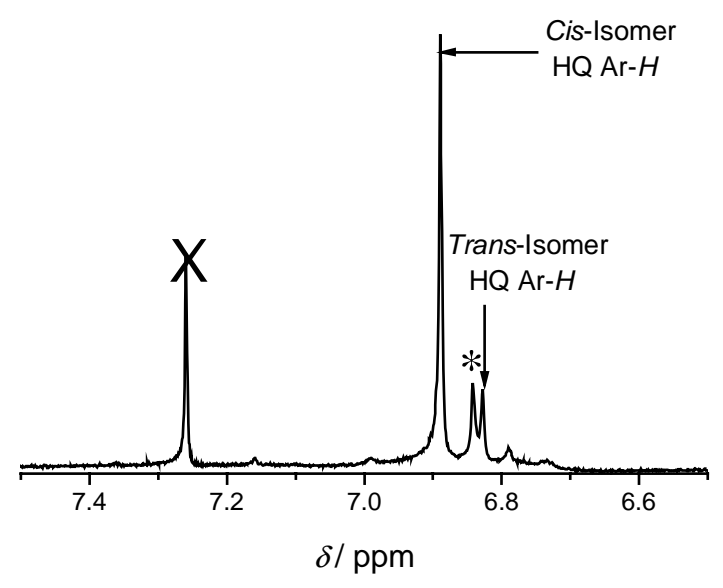

Figure S6. Partial ${ }^{1} \mathrm{H}$ NMR spectrum displaying the aromatic region $\left(300 \mathrm{MHz}, \mathrm{CDCl}_{3}\right)$ of the PTSA treated bismacrocycle 6 recorded at $298 \mathrm{~K}$. The peak marked by an asterisk $(*)$ arises from the contamination of the bismacrocycle 6 with the starting material 4.

\section{CHARACTERIZATION OF THE [2]CATENANE 1•4PF $6 \mathrm{BY}^{1} \mathrm{H}$ NMR SPECTROSCOPY}

The [2]catenane $1 \bullet 4 \mathrm{PF}_{6}$ synthesized from the PTSA treated predominately (9:1) cis-isomeric bismacrocycle 6 was analyzed by ${ }^{1} \mathrm{H}$ NMR spectroscopy. An overall simplification of the entire spectrum (Figure S7) is observed which indicates that the isolated [2]catenane $1 \bullet 4 \mathrm{PF}_{6}$ exist mainly as a single isomer (95\%) when synthesized from the predominately cis-isomeric (9:1) macrocycle. By the deduction argument this can be assigned to the cis-isomer.

It is not directly possible to determine from ${ }^{1} \mathrm{H}$ NMR spectroscopy whether it is the cis- or the trans-isomer of the [2] catenane $1 \mathbf{1}^{-4 \mathrm{PF}_{6}}$ that has been isolated. This is because of the fact that both isomeric forms of the [2] catenanes belong to similar types of point group as the cis-1•4PF $\mathrm{PF}_{6} C_{2 \mathrm{~h}}$, whereas the trans-1•4PF 6 is $C_{2}$. This implies that both the cis- and the trans-isomer of the [2]catenane $1 \bullet 4 \mathrm{PF}_{6}$ exhibit one signal observed as a doublet for the resonances associated with the protons for $H_{\alpha}, H_{\beta}$, etc., thereby making the two compounds indistinguishable by ${ }^{1} \mathrm{H}$ NMR spectroscopy. 


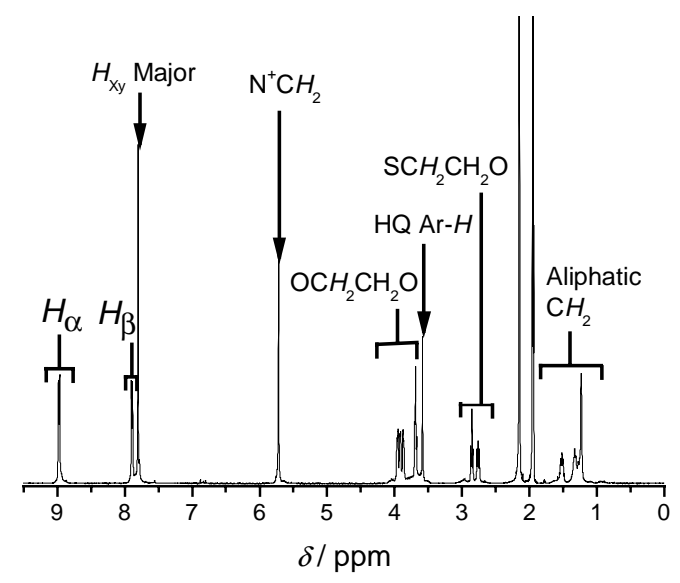

Figure S7. Full ${ }^{1} \mathrm{H}$ NMR spectrum recorded at $298 \mathrm{~K}\left(400 \mathrm{MHz}, \mathrm{CD}_{3} \mathrm{CN}\right)$ of the predominately cis-isomeric [2]catenane $1 \bullet 4 \mathrm{PF}_{6}$ isolated from the high-pressure clipping reaction carried out on the 9:1 cis-/trans-isomeric bismacrocycle 6.

\section{CHARACTERIZATION BY UV-vis-NIR ABSORPTION SPECTROSCOPY.}

To test the assumption that the steric bulk of the TTF derivative $\mathbf{5}$ prevents it from forming an inclusion complex with $\mathrm{CBPQT}^{4+}$, equimolar amounts of the two components were mixed in $\mathrm{Me}_{2} \mathrm{CO}$. The mixing of the two components, had no observable visual effect, for which the initial yellow color originating from the localized transition of the TTF unit at $380 \mathrm{~nm}$ was not affected (Figure S8), and more importantly, no CT transition was observed around 700-850 nm even several hours after mixing $\mathbf{5}$ and $\mathbf{C B P Q T}{ }^{4+}$. The lack of a CT band is strong evidence in support of the conclusion that [2]pseudorotaxane formation does not take place between the bulky TTF macrocycle $\mathbf{5}$ and $\mathrm{CBPQT}^{4+}$. These data also indicate that no significant alongside interaction is present in solution between the free bulky TTF unit $\mathbf{5}$ and the tetracationic cyclophane, even when cooling the sample or going to high concentrations. ${ }^{6}$ This is thought to be a result of the restricted nature of the TTF unit, which distorts the $\pi$-surface of the molecule, thereby making it less efficient in interacting with $\mathrm{CBPQT}^{4+}$, as well as the presence of two cyanoethylthio protection groups, which significantly decreases the $\pi$-electron donating properties of $\mathbf{5}$. 


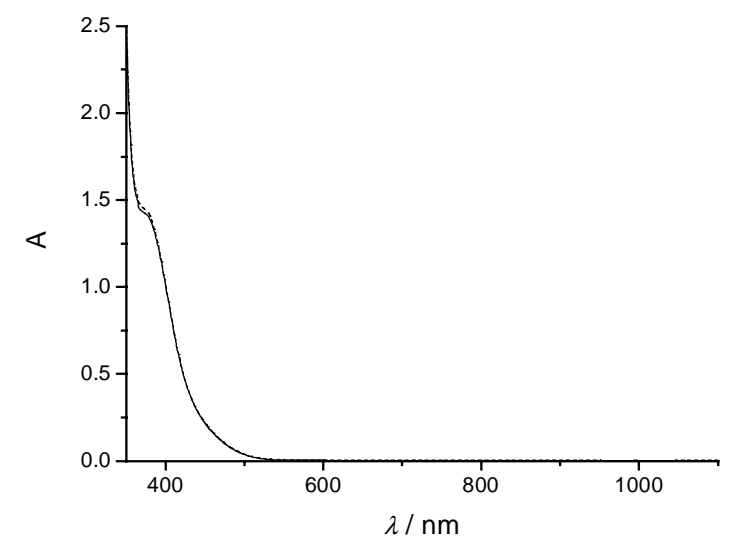

Figure S8. Absorption spectra of the TTF unit 5 before (solid line) and after (dashed line) mixing with equimolar amounts of the host $\mathrm{CBPQT}^{4+}$ in $\mathrm{Me}_{2} \mathrm{CO}$ at room temperature.

\section{Evaluation of the maximum CT band intensity of a pure cis or trans-isomer of $1.4 \mathrm{PF}_{6}$}

1•4PF 6 (67:33 cis/trans) in $\mathrm{MeCN}: \quad \varepsilon=1475 \mathrm{M}^{-1} \mathrm{~s}^{-1}$

1•4PF $(95: 5$ cis/trans $)$ in $\mathrm{MeCN}: \quad \varepsilon=550 \mathrm{M}^{-1} \mathrm{~s}^{-1}$

Defines the absorption intensity to be $\mathrm{X}=$ cis and $\mathrm{Y}=$ trans

This gives us the following two first order equations:

(1) $67 \mathrm{X}+33 \mathrm{Y}=1475 \mathrm{M}^{-1} \mathrm{~s}^{-1}$

(2) $95 \mathrm{X}+5 \mathrm{Y}=550 \mathrm{M}^{-1} \mathrm{~s}^{-1}$

From the combination of the two expressions we find that:

$\mathrm{X}=3.8 \mathrm{M}^{-1} \mathrm{~s}^{-1}$ and $\mathrm{Y}=36.9 \mathrm{M}^{-1} \mathrm{~s}^{-1}$

This allows us to estimate the CT band intensity of a hypothetical [2] catenane $1 \bullet 4 \mathrm{PF}_{6}$ consisting exclusively of either the cis- or the trans-isomer:

$\varepsilon($ all Cis $) \quad=100 \times \mathrm{X}=380 \mathrm{M}^{-1} \mathrm{~s}^{-1}$

$\mathcal{E}($ all Trans $)=100 \times \mathrm{Y}=3690 \mathrm{M}^{-1} \mathrm{~s}^{-1}$ 


\section{MOLECULAR MODELLING}

The conformational degrees for freedom for the cis- and the trans-isomer of the [2]catenane $\mathbf{1}^{4+}$ were probed by running a molecular dynamics simulation with a 1 ns equilibration followed by a 10 ns production during which 1000 structures were collected. Reoptimization of the 1000 structure produced conformations with an energy spread of $34 \mathrm{~kJ} \mathrm{~mol}^{-1}$ for the trans-isomer, while all 1000 structures for the cis-isomer were within $4 \mathrm{~kJ} \mathrm{~mol}^{-1}$ of each other. All the trans-structures are of a face-to-face geometry, and all of the cis-structures are with a non-perpendicular edge-to-face alignment (Figure S9). The lowest energy structure for each isomer was re-optimized at the B3LYP/6-31G(d) level. In order to evaluate possible cis-1 $\mathbf{1}^{4+}$ face-to-face conformations, a trial structure was generated from the optimized geometry of the trans-isomer of $\mathbf{1}^{4+}$, by changing the aliphatic linker chain to a cis-conformation. The linker and PEG chain were then relaxed by keeping the $\mathrm{CBPQT}^{4+}$ and TTF units fixed, followed by a full geometry optimized which returned the geometry to an edge-to-face alignment. Similarly, starting an optimization from the X-ray structure for the cis-isomer produced a face-to-edge geometry.

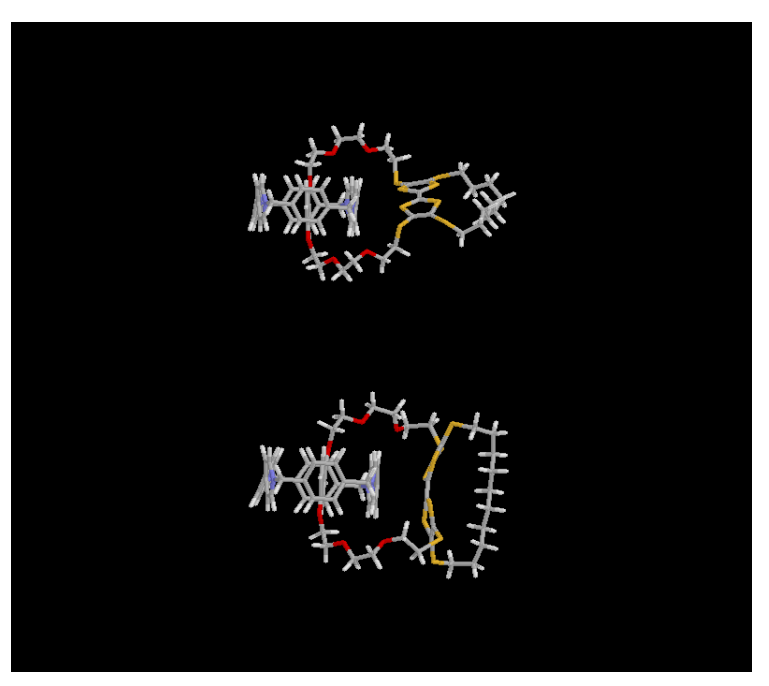

Figure S9. Optimized geometries at the B3LYP/6-31G(d) level of (a) the cis-isomer of $\mathbf{1}^{4+}$ and (b) the trans-isomer of $\mathbf{1}^{4+}$. 


\section{CHARACTERIZATION BY RAMAN SPECTROSCOPY}

The following [2]pseudorotaxane, $\mathbf{9} \subset \mathbf{C B P Q T}{ }^{4+}$, was formed between the model TTF compound ${ }^{4} \mathbf{9}$ and CBPQT $^{4+}$ in order to assign and evaluate the enhancement of signals being resonantly enhanced in the resonance Raman spectra of the complex compared to the free components.
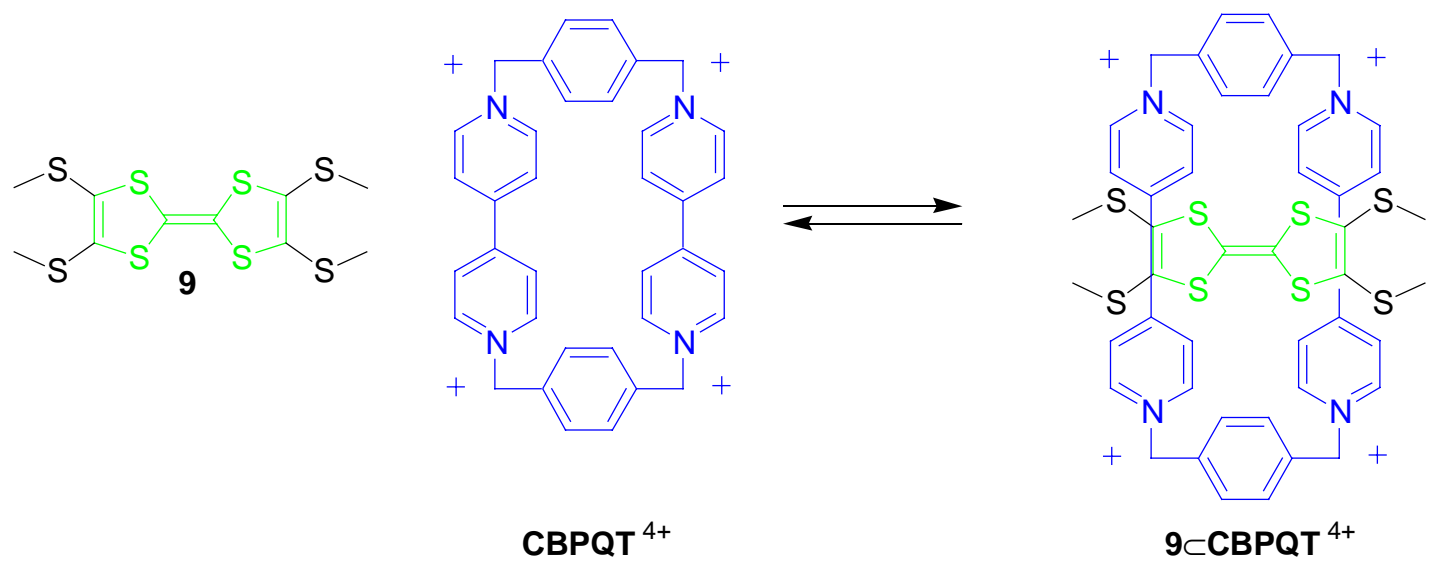

Scheme S1. [2]Pseudorotaxane formation between the model TTF derivative 9 and $\mathbf{C B P Q T}^{4+}$.

The [2]pseudorotaxane $9 \subset \mathrm{CBPQT}^{4+}$ was formed by 1:1 mixing of the TTF model compound 9 and $\mathrm{CBPQT}^{4+}$ at room temperature in MeCN. The initially yellow solution was left to equilibrate for 2 hours during which period of time an intense green solution formed. The Resonance Raman spectrum was then recorded (Figure S10). The non-resonance solution state Raman spectrum of the model TTF compound 9 and $\mathbf{C B P Q T}^{4+}$ were recorded as well for comparison. 


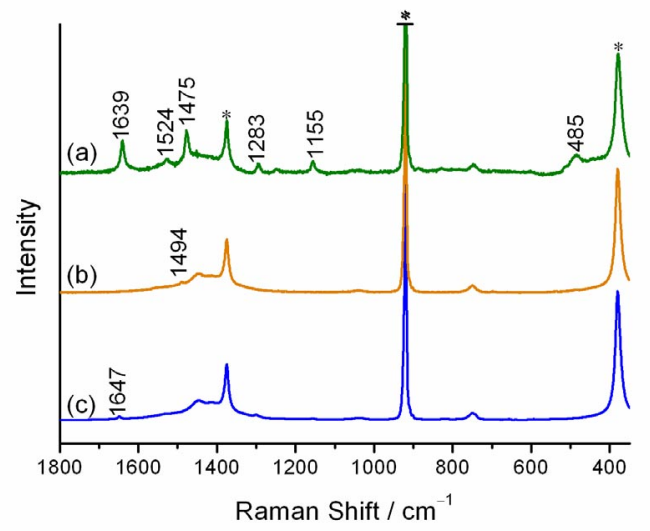

Figure S10. Raman spectroscopic data of $4.5 \mathrm{mM} \mathrm{MeCN}$ solution of (a) the [2]pseudorotaxane 9СCBPQT ${ }^{4+}$ (b) the TTF model compound 9, and (c) $\mathrm{CBPQT}^{4+}$. MeCN features as marked by an asterisk $(*)$.

In the solution state spectra of $\mathbf{1}^{4+}$ (Figure 7) and $\mathbf{9} \subset \mathbf{C B P Q T} \mathbf{C}^{4+}$ (Figure S10) at $785 \mathrm{~nm}$ excitation, it is evident that there has been a simplification with fewer signals being now resonantly enhanced over and above the normal Raman spectra of simply the components parts. These solution-phase and solid-state spectra provide a basis to assign and measure the degree of enhancement for each vibrational band relative to the isolated solvent band at $919 \mathrm{~cm}^{-1}$. The following analysis (Table S2) is uncorrected for self-absorption effects of the two absorbing samples $\mathbf{1}^{4+}$ and $\mathbf{9} \subset \mathbf{C B P Q T} \mathbf{T}^{4+}$. 
Table S2. Raman spectroscopic data of $4.5 \mathrm{mM} \mathrm{MeCN}$ solutions of (a) all cis [2]catenane $\mathbf{1}^{4+}$, (b)

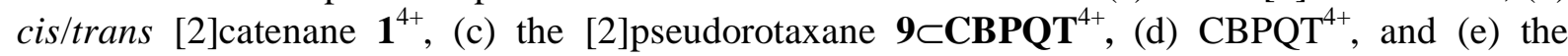
bismacrocycle 6 recorded at $785 \mathrm{~nm}$ laser excitation.

\begin{tabular}{|c|c|c|c|c|c|}
\hline & $(95: 5$ cis/trans $)$ & $(67: 33$ cis/trans $)$ & $\mathbf{9} \subset \mathbf{C B P Q T}^{\mathbf{4 + a}, b}$ & $\mathrm{CBPQT}^{4+a}$ & $6^{a}$ \\
\hline & $\mathbf{1}^{4+a}$ & $\mathbf{1}^{4+a}$ & & & \\
\hline 1639 & 0.13 & 0.61 & 0.13 & 0.02 & - \\
\hline 1551 & - & - & - & - & 0.03 \\
\hline 1533 & 0.06 & 0.32 & 0.06 & 0.02 & - \\
\hline 1483 & 0.10 & 0.36 & 0.16 & - & 0.06 \\
\hline 1294 & 0.06 & 0.33 & 0.04 & 0.03 & - \\
\hline 1247 & 0.02 & 0.26 & 0.02 & - & - \\
\hline 1157 & 0.05 & 0.34 & 0.04 & 0.02 & - \\
\hline 486 & 0.04 & 0.33 & 0.07 & - & 0.01 \\
\hline
\end{tabular}

The selective enhancement of bands associated with TTF donor and bipyridinium acceptor in both $\mathbf{1}^{4+}$ and $\mathbf{9} \subset \mathbf{C B P Q T}^{4+}$ confirms the CT band assignment of $715 \mathrm{~nm}$ absorption observed in $\mathbf{1}^{4+}$.

The [2]pseudorotaxane $\mathbf{2} \subset \mathbf{C B P Q T}^{4+}$ was formed by 1:1 mixing of the HQ model compound $\mathbf{2}$ and $\mathrm{CBPQT}^{4+}$ at room temperature in MeCN. The initially colourless solution was left to equilibrate for 2 hours during which period of time an intense red solution formed. The Raman spectrum was then recorded (Figure S11). 


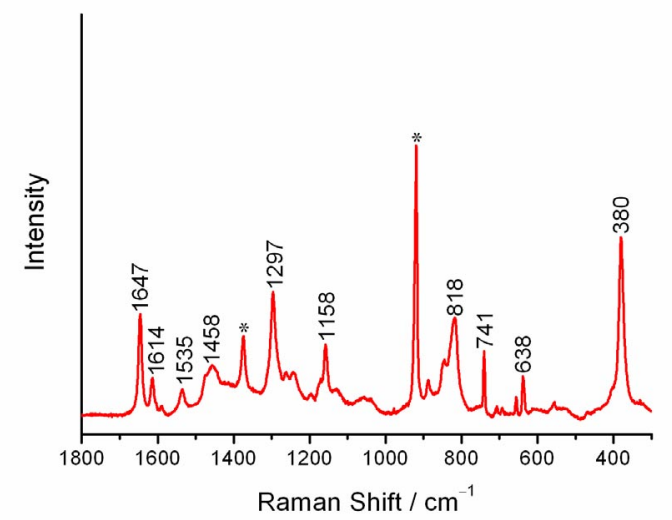

Figure S11. Raman spectroscopic data of a $110 \mathrm{mM} \mathrm{MeCN}$ solution of the [2]pseudorotaxane $2 \subset \mathrm{CBPQT}^{4+}$.

In addition to the solution studies done on $4.5 \mathrm{mM}$ solutions in $\mathrm{MeCN}$ of $\mathbf{1}^{4+}, \mathrm{CBPQT}^{4+}, \mathbf{6}$, the TTF derivative 9 (Scheme S1), $9 \subset \mathbf{C B P Q T}^{4+}$, and the [2]pseudorotaxane ${ }^{7} \mathbf{2} \mathbf{C B P Q T}^{4+}$ the same series of compounds and complexes were characterized in the solid state. These data were recorded in order to provide spectra that were not obscured by solvent peaks, thereby providing corroboration of each compound and complex overall Raman signature at $\lambda_{\mathrm{exc}}=785 \mathrm{~nm}$. The range of bands observed (Figure S12) in the solid state ${ }^{8}$ spectrum of the [2]catenane $\mathbf{1}^{4+}$ can be readily observed in the corresponding solution state spectrum as well as of $\mathbf{9} \subset \mathbf{C B P Q T}^{4+}$ in solution.

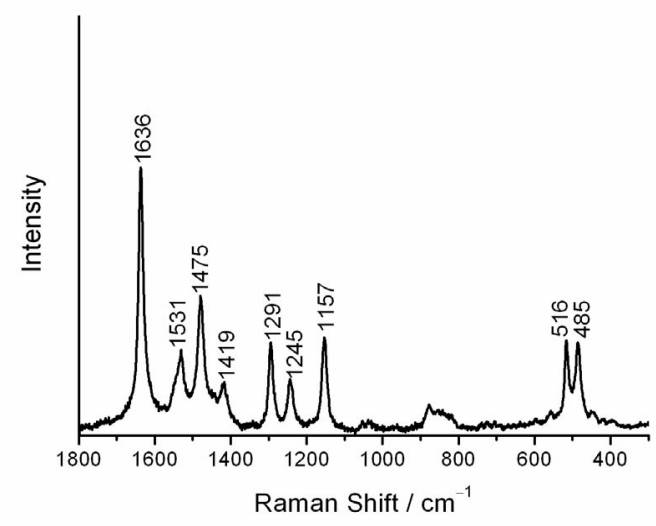

Figure S12. Resonantly enhanced Raman spectra of the solid [2]catenane $1 \bullet 4 \mathrm{PF}_{6}$ recorded at $785 \mathrm{~nm}$ laser excitation. 
The solid state Raman spectra of $\mathbf{C B P Q T}^{4+}$ displays a wealth of bands (Figure S13) which are presumably assigned to both the bipyridinium and the para-xylene ring systems of which only a few are observed in the solution phase spectrum consistent with the non-resonant conditions.

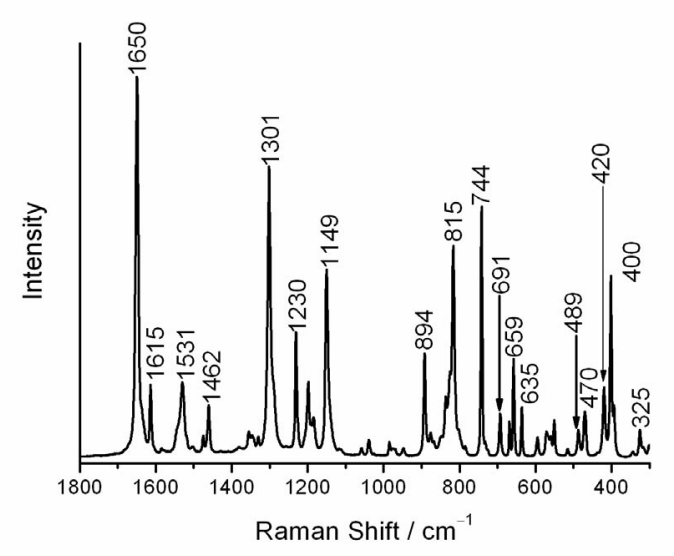

Figure S13. Non-resonantly enhanced Raman spectra of solid CBPQT ${ }^{4+}$ recorded at $785 \mathrm{~nm}$ laser excitation.

Similarly, the spectrum of the bismacrocycle 6 (Figure S14) is non-resonantly enhanced and is thereby representative of the totally symmetric vibrations of both the TTF core as well as the HQ donor, which can be readily discerned by comparison to the model TTF unit 9 (Figure S15). This comparison indicates that the TTF unit has a larger Raman scattering cross section than the HQ unit. 


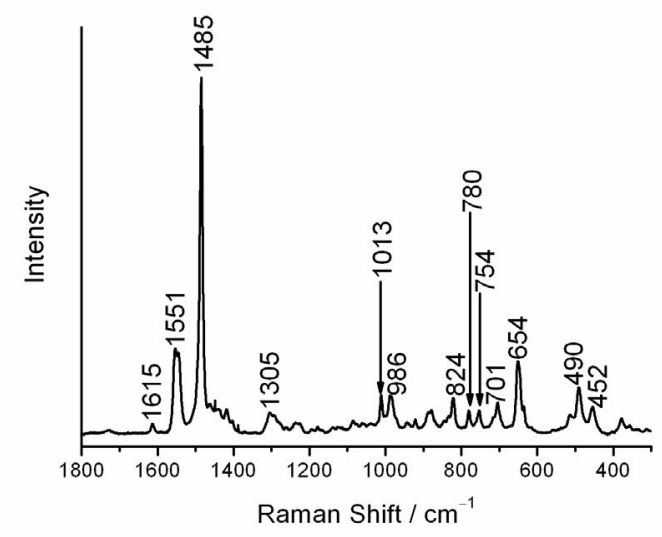

Figure S14. Non-resonantly enhanced Raman spectra of the solid 1:1 isomeric mixture of the bismacrocycle 6 recorded at $785 \mathrm{~nm}$ laser excitation.

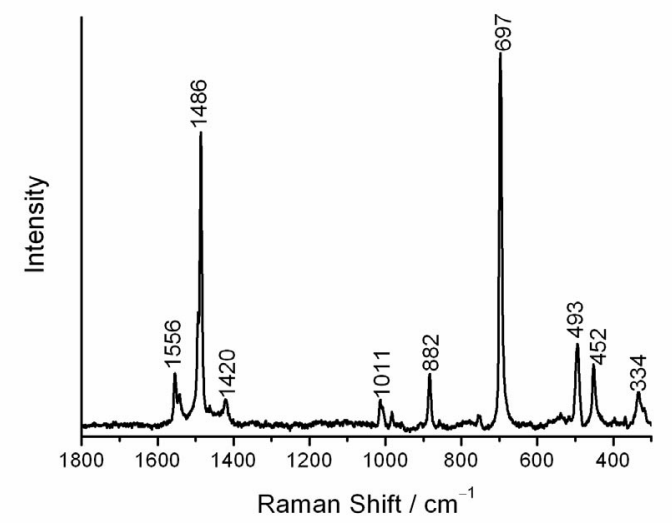

Figure S15. Non-resonantly enhanced Raman spectra of the solid TTF model compound 9 recorded at $785 \mathrm{~nm}$ laser excitation.

\section{COMPLETE REFERENCES OF THE MAIN TEXT}

(15a) Anelli, P.-L.; Ashton, P. R.; Ballardini, R.; Balzani, V.; Delgado, M.; Gandolfi, M. T.; Goodnow, T. T.; Kaifer, A. E.; Philp, D.; Pietraszkiewicz, M.; Prodi, L.; Reddington, M. V.; Slawin, A. M. Z.; Spencer, N.; Stoddart, J. F.; Vicent, C.; Williams, D. J. J. Am. Chem. Soc. 1992, 114, 193-218.

(41b) Anelli, P.-L.; Asakawa, M.; Ashton, P. R.; Bissell, R. A.; Clavier, G.; Górski, R.; Kaifer, A. E.; Langford, S. J.; Mattersteig, G.; Menzer, S.; Philp, D.; Slawin, A. M. Z.; Spencer, N.; Stoddart, J. F.; Tolley, M. S.; Williams, D. J. Chem. Eur. J. 1997, 3, 1113-1135. 


\section{REFERENCES}

(1) Heilmayer, W.; Wallfisch, B.; Kappe, C. O.; Wentrup, C.; Gloe, K.; Kollenz, G. Supramolecular Chem. 2003, 15, 375-383.

(2) Nygaard, S.; Flood, A. H.; Jeppesen, J. O.; Bond A. D. Acta Cryst. C 2006, available online.

(3) Anneli, P.-L.; Ashton, R.; Ballardini, R.; Balzani, V.; Gandolfi, M. T.; Goodnow, T. T.; Kaifer, A. E.; Philp, D.; Pietraszkiewicz, M.; Prodi, L.; Reddington, M. V.; Slawin, A. M. Z.; Spencer, N.; Vicent, C.; Williams, D. J. J. Am. Chem. Soc. 1992, 114, 193-218.

(4) Svenstrup, N.; Rasmussen, K. M.; Hansen, T. K.; Becher, J. Synthesis 1994, 8, 809-812.

(5) The ${ }^{13} \mathrm{C}$ NMR spectroscopic data listed are for the major cis-isomer. A set of low intensity peaks corresponding to the trans-isomer was also observed but are disregarded here for simplicity.

(6) A concentration range of $1.4 \times 10^{-4} \mathrm{M}$ to $8.6[0] \times 10^{-4}$ was used to test the complexation between the TTF macrocycle $\mathbf{5}$ and equimolar amounts of the tetracationic cyclophane

\section{CBPQT $^{4+}$.}

(7) The solution phase Raman spectrum of the [2]pseudorotaxane was recorded on a $110 \mathrm{mM}$ solution of the 1:1 complex.

(8) The resonance Raman spectra of the microcrystalline samples of the [2]catenane $1 \bullet 4 \mathrm{PF}_{6}$ as both the (67:33) and (95:5) cis/trans isomeric mixture and the solid-state cis-isomeric crystals were investigated but no significant difference was observed in the spectra of these compounds. 